\title{
СТРАТЕГІЯ ТА ПЕРСПЕКТИВИ СТВОРЕННЯ В УКРАЇНІ БАГАТОРІВНЕВИХ КОМП'ЮТЕРНИХ МЕРЕЖ 3 ВІДКРИТИМИ ОПТИЧНИМИ КАНАЛАМИ
}

\author{
Ярослав Николайчук, Юрій Кудряшов, Василь Яцків, Тарас Лендюк
}

\begin{abstract}
Ярослав Николайчук - Тернопільська академія народного господарства, кафедра спеціалізованих комп'ютерних систем, площа Перемоги, 3, 46004, Тернопіль, Україна, д.т.н., професор, завідувач кафедри

Юрій Кудряшов - Науково-промислова асоціація, вул. Кутузова 17/8, Київ, Україна

Василь Яцків - Тернопільська академія народного господарства, кафедра спеціалізованих комп'ютерних систем, площа Перемоги, 3, 46004, Тернопіль, Україна, к.т.н., старший викладач

Тарас Лендюк - Тернопільська академія народного господарства, кафедра інформаційно-обчислювальних систем та управління, площа Перемоги, 3, 46004, Тернопіль, Україна, e-mail: tl@tanet.edu.te.ua, інженер-програміст.
\end{abstract}

Анотація: $B$ статті аналізуються проблеми $і$ напрямки створення широкого класу розподілених комп'ютерних мереж та ефективних принципів кодування даних при реалізаціі циифрових каналів зв 'язку. Автори розглядають напрямки розвитку діапазону систем частотної передачі оптичних сигналів для даних багаторівневих комп'ютерних мереж. Порівнюються переваги волоконно-оптичних ліній зв'язку з використанням відкритих оптичних каналів. Показано перспективи розвитку розподілених комп'ютерних мереж на основі відкритих оптичних каналів. В статті також наводяться теоретичні основи побудови багаторівневих комп'ютерних мереж з відкритими оптичними каналами. Також наводиться архітектура різних класів багаторівневих комп'ютерних мереж з відкритими оптичними каналами. Крім того розглядаються переваги використання комп'ютерних мереж які використовують відкриті оптичні канали.

Ключові слова: комп'ютерні мережі, циифрові канали зв 'язку, відкриті оптичні канали, активні оптичні ретранслятори.

\section{1. ВСТУП}

В Україні на даному етапі розвитку державотворчих процесів поряд з іншими проблемами стратегічне значення має швидке вирішення проблем інформатизації всіх галузей народного господарства. Важливу роль при цьому відіграють напрямки створення широкого класу розподілених комп'ютерних мереж [1].

Особливе значення при вирішенні цихзадач має розробка ефективних принципів кодування даних реалізації цифрових каналів зв'язку, які б забезпечували умовам національної безпеки та захисту інформаційного простору України в цілому.

Перспективним напрямком вирішення перелічених актуальних завдань, як це доказує світовий досвід є освоєння оптичного діапазону частот, створення та масовий випуск на їх основі систем передавання даних в багаторівневих комп'ютерних мережах. В даний час $є$ два альтернативні вирішення цієї проблеми на основі:

- Волоконно-оптичних ліній зв'язку (ВОЛЗ) [2];

- Відкритих оптичних каналів (ВОК).

При цьому не відкидаючи глобальної державної перспективи розвитку інформаційнихмереж на основі ВОЛЗ, особливо при використанні ідеї прокладки волоконних кабелів вздовж полотен магістральних залізниць та всередині захисної провідної лінії високовольтних електромереж, конкретну перспективу має розвиток розподілених комп'ютерних мереж (РКМ) на основі ВОК.

Головним обмеженням для масового застосування ВОЛС є необхідність їх фізичної прокладки та спеціальних умов експлуатації, наприклад в вакуумних оболонках при забезпеченні необхідного рівня захисту від несанкціонованого доступу. Такі лінії зв’ язку непридатні для обслуговування мобільних об'єктів та низових рівнів комп'ютерних мереж, для обслуговування великого числа розподілених об'єктів управління та комп'ютеризованих абонентів. Порівняння засобів безпровідного радіозв'язку з реалізацією РКМ ВОК показує набутий світовий досвід експлуатації останніх в США [3], Росії [4] та Україні [5].

\section{2. ПЕРСПЕКТИВИ ВОК}

Використання ВОК має наступні переваги: 1. Низькі затрати на реалізацію та експлуата- 
цію оптичних активних ретрансляторів (ОАР);

2. Висока завадозахищеність каналів та складність організації несанкціонованого доступу, внаслідок вузької діаграми направленості оптичних сигналів;

3. Проста реалізація багаторівневих архітектур для обслуговування низових рівнів РКМ;

4. Широкі можливості створення РКМ ВОК вздовж тих же самих магістральних та місцевих залізниць та високовольтних мереж без прокладки лінійних фізичних комунікацій;

5. Спрощення схеми каналоутворення на основі концентраторів та різношвидкісних систем передавання даних на різних рівнях PKM.

\section{3. АРХITЕКТУРА РКМ ВОК}

В плані вищесказаного стратегія створення в Україні, освоєння випуску та масового впровадження РКМ ВОК в різні галузі народного господарства полягає в реалізації наступ- них чотирьох їх класів, які відрізняються системними параметрами та архітектурою.

1. Високошвидкісні дуплексні РКМ ВОК (Рис. 1)

2. Середньошвидкісні кільцеві РКМ ВОК (Рис.2)

3. Низькошвидкісні кільцеві (Рис.3)

4. Розгалужені РКМ ВОК (Рис.4)

На рисунках 1-4 позначено: ОУ - об'єкт управління; КМ - комп 'ютерна мережа; ОАР оптичний активний ретранслятор; ОСР оптичний сканований ретранслятор; СОМ сканований оптичний модулятор. В таблиці 1 приведені рекомендовані різні швидкості обміну даними для РКМ ВОК різних рівнів.

Високошвидкісна РКМ ВОК (Рис.1.), як правило, використовується для об'єднання двох віддалених комп'ютерних мереж, що обслуговують окремі розподілені ОУ. Найважливіша вимога до такої РКМ - максимальна швидкість передавання даних в дуплексному режимі при
$\mathrm{KM}$

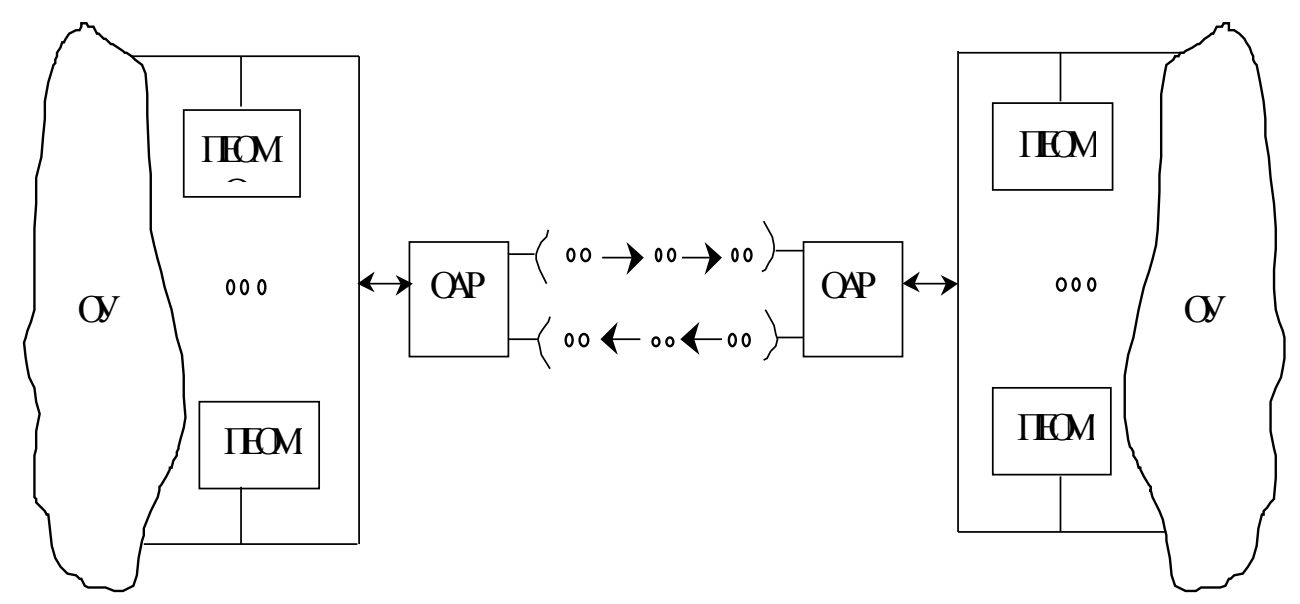

Рис.1. Високошвидкісні дуплексні РКМ ВОК
KM

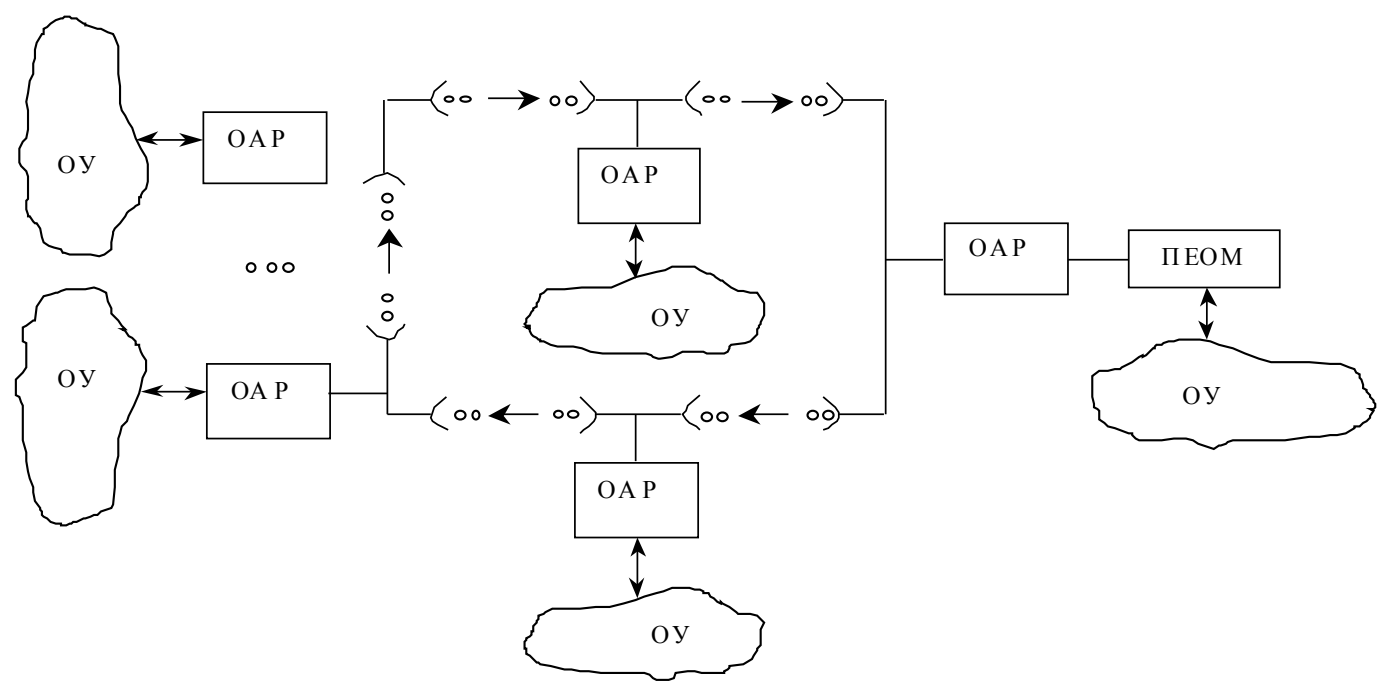

Рис.2. Середньошвидкісні кільцеві РКМ ВОК 


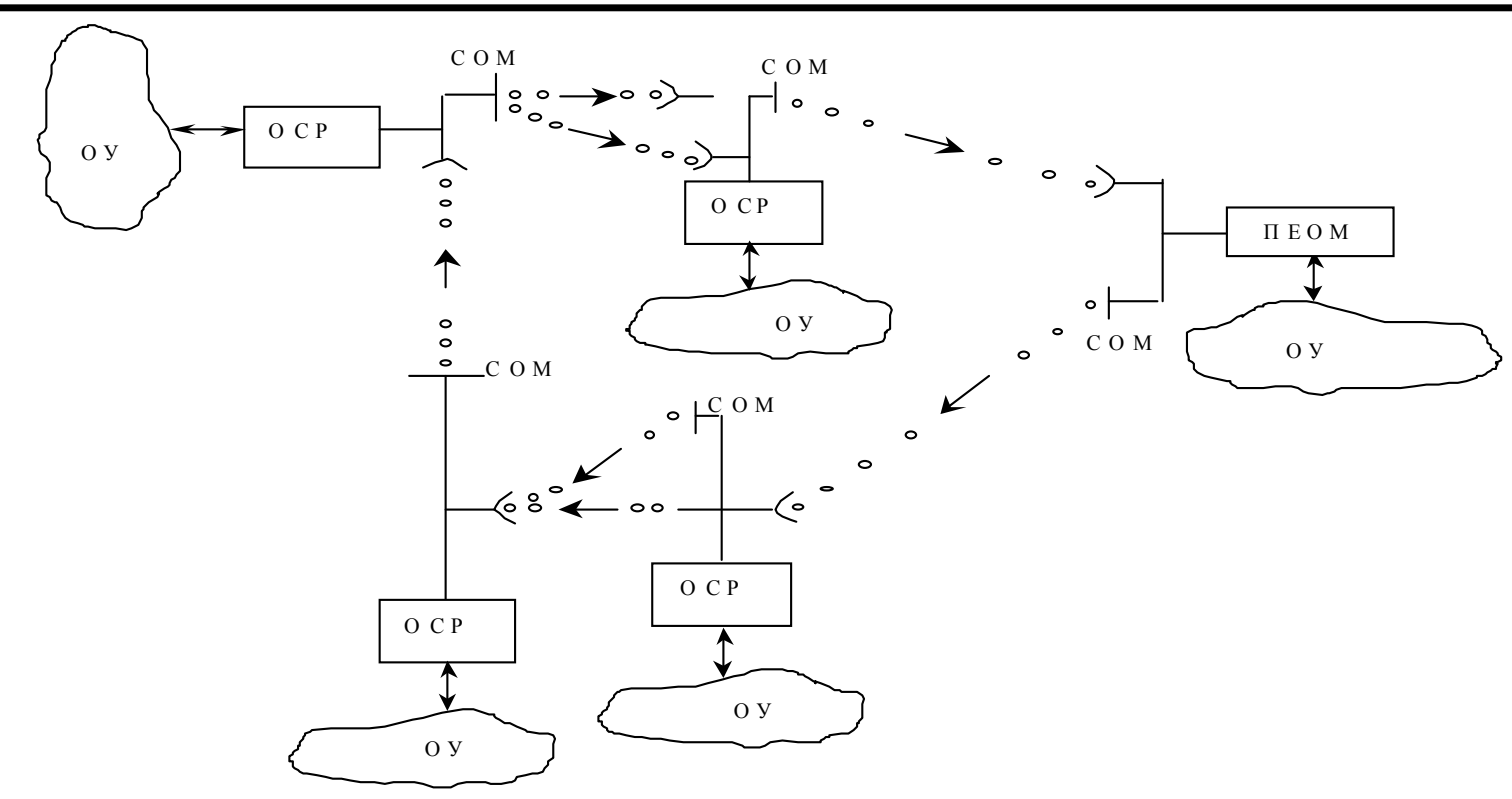

Рис.3. Низькошвидкісні кільцеві РКМ ВОК

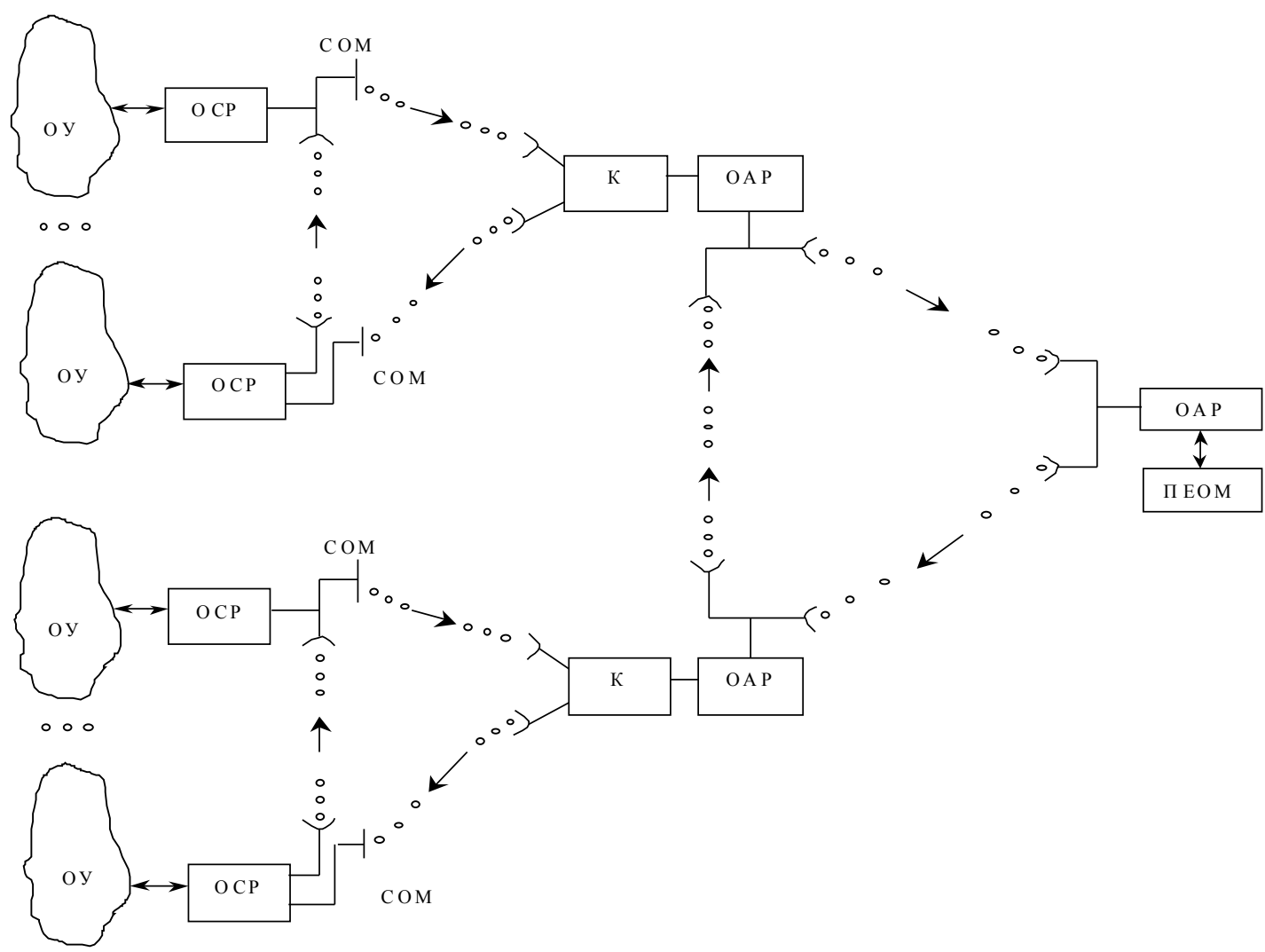

Рис.4. Розгалужені РКМ ВОК

відносно невеликих віддалях між ОАР, що не перевищують одного кілометра. Основним обмеженням масового застосування таких РКМ є висока вартість ОАР, оснащених потужними лазерними випромінювачами.

Середньошвидкісна РКМ ВОК (Рис. 2) організована на базі кільцевої естафетної архітектури є перспективною для широкого класу розподілених ОУ, наприклад, нафтогазовидобувних та енергетичних підприємств, екологічного та охоронного моніторингу. Швидкість передавання даних в таких мережах може бути обмежена до 10 Мбіт/с, а віддалі між ОАР - до 3 км.

Головним обмеженням широкого застосування таких РКМ ВОК є жорсткі кліматичні умови експлуатації ОАР, малі габарити та низька вартість. Однією з проблем забезпечення надійної роботи ВОК $є$ спрощення процедур юстировки оптичних передавачів та приймачів, 
Характеристики РКМ ВОК різних типів

\begin{tabular}{|l|l|c|c|c|}
\hline № & \multicolumn{1}{|c|}{ Тип РКМ ВОК } & $\begin{array}{c}\text { Число } \\
\text { каналів }\end{array}$ & $\begin{array}{c}\text { Швидкість } \\
\text { передачі даних }\end{array}$ & $\begin{array}{c}\text { Віддаль між } \\
\text { ретрансляторами (м) }\end{array}$ \\
\hline 1 & Високошвидкісні & 1024 & 100 Мбіт/c & 1000 \\
\hline 2 & Середньошвидкісні & 256 & 10 Мбіт/c & 2000 \\
\hline 3 & Низькошвидкісні & $8-32$ & 1 Мбіт/с & $100-500$ \\
\hline 4 & Розгалуженні & $12-32$ & 2,4 Кбіт/c & 3000 \\
\hline
\end{tabular}

та реалізація можливостей самоюстировки при впливі низькочастотних вібрацій та просторових поворотів і переміщень оптичних систем ОАР в процесі експлуатації в промислових умовах. В таких РКМ ВОК ефективно можуть використовуватись дешеві інфрачервоні світлодіодні випромінювачі.

Кільцева та розгалужена низькошвидкісні РКМ ВОК (Рис. 3, Рис. 4) організовані на основі COM забезпечують самоюстіровку випромінювача і приймача ОСР при значних кутових та лінійних переміщеннях СОМ. Це дозволяє розміщати СОМ на висотних будинках, вишках та спеціальних щоглах. Головним обмеженням щодо швидкості передавання даних є пропускна здатність оптичного модулятора COM, a віддаль між ОСР та СОМ зменшується внаслідок подвійної віддалі проходження оптичних сигналів та часткового їх поглинання в СОМ. В якості СОМ можна використовувати рідкокристалічні катафотні матеріали з швидкостями модуляції до 2,4 Кбіт/с.

РКМ на основі ВОК добре пристосовані для інформаційного забезпечення розподілених, територіально віддалених та спеціальних ОУ, тому при вирішенні проблем їх створення оперативно повинні вирішуватись задачі глибокого дослідження ОУ як джерел інформації та розробки їх інформаційних моделей [5]. Теоретичні дослідження та вдосконалення математичного апарату інформаційних моделей ОУ дозволить ефективно вирішити задачі зменшення надлишковості інформації, а це в свою чергу дозволить суттєво знизити вимоги до граничних швидкостей передавання даних на різних рівнях РКМ, а також знизить вартість оптичних ретрансляторів та збільшить віддалі передавання даних в РКМ при заданій їх достовірності і рівнях захисту.

\section{4. ВИКОРИСТАННЯ ВОК}

Застосування комп'ютерних мереж, 3 використання відкритого оптичного каналу може бути перспективним в наступних сферах:
1) при побудові та впровадженні автоматизованих охоронних систем контролю станів важливих об'єктів;

2) при реалізації комп'ютерних систем контролю та обліку витрат енергоносіїв;

3) при контролі та управлінні розподілених об'єктів нафтової, енергетичної та атомної промисловості;

4) при реалізації екологічного моніторингу та моніторингу сільськогосподарських угідь, систем водопостачання та інше;

5) при створенні систем оперативної оцінки собівартості виробництва;

6) моніторингу руху транспортних засобів;

7) створенні мережі доступу до Internet ресурсів.

\section{5. ВИСновки}

Таким чином, створення теорії, техніки та реалізація РМК ВОК дозволить вирішити ряд актуальних задач інформатизації різних галузей народного господарства України, створити реальну основу для проектування та широкого впровадження проблемно-орієнтованих та спеціалізованих комп’ютерних мереж.

\section{6. СПИСОК ЛІТЕРАТУРИ}

[1] В.Т.Олифер, Н.А.Олифер. Компьютерные сети. Приниипы, технологии, протокольл. -СПб:Питер, 2000, 672c.

[2] Чепусов Е., Шаронин С. Оптическая связь без оптоволокна // LAN Magazine (Русское издание), 1996, № 8.

[3] Чепусов Е.Н., Шаронин С.Г. Лазерная связь - еще один способ беспроводной связи / / Сети, 1996, № 8.

[4] Яцків В.В. Лазерна система дистанційного контролю глибинно-насосних установок // Методи та прилади контролю якості, 1998, №2. -с.61-63.

[5] Николайчук Я.М., Сегін А.І. Моделі джерел інформації та методи їх представлення // Методи та прилади контролю якості. ІФДТУН, 1998, №2. -c.80-84. 


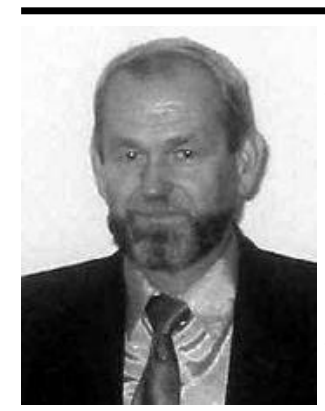

Николайчук Я. М. в 1967 роиі закінчив Львівський політехнічний інститут за спеціальністю 05.13.05 "Елементи та пристрої обчислювальної техніки та систем керування", професор кафедри спеціалізованих комп'ютерних систем Інституту комп'ютерних інформаційних технологій

Тернопільської академіїнародного господарства, академік Української академії наук національного прогресу, заступник директора Інституту комп'ютерних інформаційних технологійз наукової роботи, керівник аспірантури за спеціальністю 05.13.05 ma 05.13.13.

Коло наукових інтересів: теоретико-числові перетворення; кодування та цифрова обробка сигналів в базисі Галуа.

В 1996 р. закінчив Івано-Франківський державний технічний універcumem нафрти і газу, фоакульmem "Автоматизації ma електрифікації” за спеціальністю "Автоматизація технологічних процесів". З 1997 р по 2000 р. навчався в аспірантурі при Івано-Франківському державному технічному університеті нафоти $і$ газу на стаціонарному відділенні. В 2001 р. захистив кандидатську дисертацію за спеціальністю 05.13.13. - "Обчислювальні машини системи та мережі ”. 32002 р. доцент кафедри "Спеціалізованих комп'ютерних систем” Тернопільської академії народного господарства.

Коло наукових інтересів: кодування та цифрова обробка повідомлень, системи передавання даних з відкритим оптичним каналом зв'язку, вертикальна інформаційна технологія в базисі Галуа, теоретико-числові перетворення в системі залишкових класів та базисі Галуа.

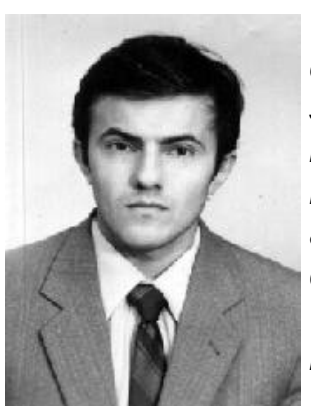

Тарас Лендюк народився в 1962 році. В 1985 році закінчив Тернопільський фінансово-економічний інститут (тепер Тернопільська академія народного господарства) за спеціальністю “Планування народного господарства” спеціалізація "Економіка".

На даний момент є аспірантом-заочником кафедри інтелектуалізованих інформаційних технологій Тернопільської академії народного господарства.

Область його наукових інтересів включає проектний менеджмент в навчальних закладах, дистанційне навчання, моделювання інтрамереж. 